\title{
Management Control of Contractual Networks: the Business Network Scorecard
}

\author{
Rosa Lombardi \\ Link Campus University of Rome \\ r.lombardi@unilink.it \\ Andrea Caputo \\ Dpt. of Business Administration \\ Princess Sumaya University for Technology \\ dr.andreacaputo@gmail.com \\ Giuseppe Russo \\ Dpt. of Economics and Law \\ University of Cassino and Southern Lazio \\ giuseppe.russo@unicas.it \\ Vincenzo Formisano \\ Dpt. of Economics and Law \\ University of Cassino and Southern Lazio \\ v.formisano@unicas.it
}

\begin{abstract}
The paper presents an analysis of the management control systems, introducing a useful instrument to summarise performance achieved from the organizational network model, with a view to establishing the competitive advantage and the creation of value on the long term. The research approach is based on the qualitative methodology. The research is developed according to the study of national and international literature. The contribution proposes theoretical proof to support the new management control instrument for contractual networks: the Business Network Scorecard. The approach adopted for the development of the network management control instrument (Business Network Scorecard) refers to the principles of the Balanced Scorecard and value creation. So, the reporting system of network performance aims at highlighting the joint results of an economicfinancial nature as well as those of an intangible nature. Through a logic of interception of large aggregates, the results achieved by the network are proposed through the matrix of network objectives, the multidimensional network model, including perspective indicators, 4 indicators of synergy and the comparison report of joint and individual performance of companies.
\end{abstract}

Keywords: management control system, business networks, contractual networks, performance, balanced scorecard, business network scorecard

This version is the paper is the Author accepted version post-review. Citation to this paper should be done as follow until the publication becomes available:

Lombardi R., Caputo A., Russo G., Formisano V. (2015), "Management Control of Contractual Networks: the Business Network Scorecard", International Journal of Applied Management Science, in-press. 


\section{Management Control of Contractual Networks: the Business Network Scorecard}

\section{Introduction}

The planning and control activities carried out by companies have guided the top company managers toward the achievement of differential performance, and towards the creation of long-term value. On one hand, the corporate decision making processes, is based on the use of informational technology instruments that are mandatory, and also some that are voluntary, including the consolidated best practices on an organizational level (Cruz and Boehe, 2008). While on the other hand, because of the complexity of the reality in business are being done, companies have requested more instruments and mechanisms suitable to identify both representation and interpretation of the economic, and non-economic results achieved in the execution of many activities (Dagnino, 2004).

The planning and control systems (Grant, 1996) found their utility in the joint decisions undertaken by several companies organized in the form of groups and company networks (Gulati et al., 2000). The decision-making process (Lombardi et al., 2014) of the groups is the result of the collaboration between several actors who share the same values, knowledge, traditions, and conflicts (Gulati et al., 2000). In knowledge economy, the Anthony model (Anthony, 1965) founded strategic planning, management, and operative control which is revisited according to the demand of planning and control activities carried out by non centralized organizational structures.

Having placed emphasis on the business network model (Thorelli, 1986), the need emerges first to handle and control organizational complexities of company networks (Trequattrini et al., 2012a). Secondly, it is imperative to identify aggregated management and measure the results achieved by it.

Social and institutional mechanisms of company networks have received a growing number of attention in the last several years (Mentzas et al., 2001). In Italy, for example, company networks have found incentives to expand in the territory, because of the framework established by the law 122/2010 with subsequent modifications. Furthermore, companies benefit from the opportunity of implementing a sustainable business model of a reticular nature, innovating in terms of products and processes, and creating joint value, which supports the launch of expansion strategies of the above networks in the international market (Chesbrough, 2003).

This scenario of contractual networks refers to the need for planning and control, that is firstly applied to the activities of each single company participating in the network and secondly, to the general activities of the network. This is achieved by measuring the action of the latter through instruments aimed at highlighting the results that derive from the intersection of activities of the companies involved in the cluster.

Through the use of ad hoc companies for management control it is possible to interpret the results of company network activities, with particular reference to contractual networks, by examining the economic performance as well as performance of an immaterial nature, achieved by each individual company and by the network in its completeness. This aspect originates from the logic of interception of the network accounts, through which the company networks can register the mutual activities carried out individually, summarizing economicfinancial elements and intangible elements (Lev, 2000).

The aim of this paper is to integrate and rejoin existing literature, starting with an analysis of the management control systems, with special reference to the reporting system by Norton and Kaplan, and the organizational network model. Its objective is to provide the academic 
and professional community with a modern governance and management instrument for company networks of a contractual nature.

Through a qualitative research method, with an inductive, and deductive approach, our proposal is to manage the network organizational model by defining a modern reporting instrument of network performance. The proposal is to build a Business Network Scorecard, revisiting the Balanced Scorecard (Kaplan and Norton, 1996) without changing the construction logic. Our research question is the following: What is the Business Network Scorecard and what importance does it have?

The article has the following structure. After the introduction, we provide a literary analysis of the management control system on the organizational network model; in particular, we focus on the Italian contractual model. Then, we describe our approach to the research. Finally, we present and discuss the findings, presents our conceptual model and draw conclusions from theory and practice.

\section{Literature Review}

\subsection{Management control systems}

Management control systems allow for a lot of information useful for company management by summarizing company performance. The assessments according to the results achieved on a company level are developed according to the Anthony model that includes management planning, and the control systems (Otley, 1999).

To build a management control system means identifying the actors involved in this kind of activity, the definition of their roles, and the objectives to be pursued. Furthermore, the actions to be undertaken as well as the knowledge available on each organizational level are shared, drastically reducing the informative asymmetries (Normann and Ramirez, 1993).

Part of the literature investigates this topic, focusing attention on company objectives, performance, and the instruments for company governance (Austin and Gittell, 2002).

In this context, the planning control activities play an important role. Camillus (Camillus, 1986) defines planning activities in connection with the undertaking of strategic decisions. Planning is an important requirement for control activities. The control activities allow for results to be controlled as well as changes compared with the action undertaken:

Control is a behavioral process that involves measurement and evaluation of the performance of organizational units, the identification of deviations from planned performance, the initiation of appropriate responses to these deviations, and the monitoring of remedial actions, all done with the objective of ensuring that the managers decisions and actions are consistent with planned organizational objectives. (Camillus, 1986)

Assessment of the cause and effect relations of management events identifies what company actions are efficient in the long term. There is a need to plan, assess, and measure activities carried out in a company and this is done by using management control instruments.

Even though some studies investigate the relationship between the external environment, organizational culture and its relation with the adoption of management control systems (Reginato and Guerreiro, 2013), another segment of the literature classifies the management control instruments as follows (Anthony, 1965):

- The obligatory instruments of a financial and economic-financial nature deriving from accounts and from balance sheets, including the indexes and cash flows.

- The instruments of preventive control such as budgets used to represent the economic-financial objectives to be achieved on the short term. 
- The control instruments of final balance as reports understood as control documents that communicate performance of the system.

The Balanced Scorecard, or BSC (Kaplan and Norton, 1996) is a modern measuring and control system which allows for the definition of our strategic company dimensions through a balanced assessment chart and a set of indicators. These dimensions comply with the definition of company objectives.

The objective of the BSC is to become a strategic company instrument (Normann and Ramirez, 1993) capable of integrating the economic-financial indicators with the intangible drivers, with a view to achieving future company performance of a traditional and immaterial nature. The Balanced Scorecard (Norreklit, 2000) can translate the company mission (Porter, 1991) into a communication model of company strategy.

According to the BSC, the balancing of company perspectives (Kaplan and Norton, 2001) include explanation of the economic-financial profile, customer, internal processes, learning, and growth. For every perspective, the strategic objectives that the organization intends to achieve are considered: performance assessment parameters, objective values, and strategic initiatives.

The financial perspective identifies the company strategy with regard to the economic results predefined by the company. Therefore, some economic-financial indicators are defined. Strategies targeted at company customers have to be identified, in order to create trust and collaboration. Customer relations have to be quantified: for example, the duration, the quality, and the volume of transactions with the customers can be useful indicators. The perspective of the internal processes defined through specific indicators are the objectives related to new management processes necessary for company competitiveness. The perspective of learning and of growth measures the resources used for the improvement process necessary to achieve the objectives.

Basically, the Balanced Scorecard examines the cause and effect relations between the objectives and the measures identified in the strategic analysis perspective. Every measure chosen belongs to a chain of cause and effect relations that allow for communication to the organization of the company strategy.

For control of company management, BSC introduces an element of innovation. The assessment of intangible aspects related to company management. In fact, the BSC report assesses, among other aspects, the strategic elements of an intangible nature (Roos et al., 1998) held by the company that are important for the achievement of differential performance.

\subsection{Business Networks and emerging features to report performance}

The planning and control activities in the context of network organizational model play a very important role as they support the management model. The governance of each business network (Trequattrini et al., 2012b) needs to be structured with the aim of representing aggregate performance.

Business networks need to be analyzed with the performance reporting systems (Lynch et al. 1991), by creating a management control system suitable to represent the objectives and strategies of the network organizational model (Rogers and Kincaid, 1981).

For this reason, it is important to recall the characteristics of the business network. The network model (Parkhe et al., 2006) involves more than one company system. It is based on formal or informal relationships, according to the methods of constitution of the aggregate through the undersigning of contracts of various kinds.

The business network represents a free company aggregation capable of creating structures, and processes that are capable of making joint decisions integrating the efforts of all participants in order to design, create, and produce goods or services, to develop new processes and products, to reduce innovation times or the time required for entrance to a market, exchange information, and other resources (Ahmad and Kitchen 2008). 
The creation of a business network implies changing the company governance mechanisms of each company involved, according to network governance.

Interaction between the aggregate companies (Grandori and Soda, 1995) allows for the achievement of differential results compared with individual action. This form of company coalition results in the sharing of knowledge (Winter, 1998) required for the execution of production processes, aiming at increasing competitiveness, and the level of innovation of the aggregate.

According to the contractual theory of the company, the network is identified in a coordination instrument of the economic activities and represents a hybrid model between market and hierarchy (Williamson, 1991). This is an alternative form to the market, and hierarchy (Powell, 2003). It is a form of coordination that uses governance mechanisms that go well beyond the market and hierarchy, as it is based on cooperation among companies, and specific methods of interaction for company partners.

According to Williamson's theory of transaction costs, the range of management mechanisms of transactions that derive from supply and demand can be identified in the market. On the other hand, the range of mechanisms based on the hierarchic authority of management can be identified in hierarchy (Coase, 1937).

The aforementioned theory identifies a set of elementary activities in economic activities, also known as transactions, and the basis of economic exchanges:

"The transfer of goods or services through an interface that can be separated technologically" (Williamson, 1991).

Development of the Williamson theory recognizes an alternative to hierarchy, and to the market as an intermediate solution. The aggregation of companies that play a different role, in accordance to the phenomenon analyzed used, for example, investments, information available, relational frequency, and so on.

According to parts of the literature (e.g. Ahmad and Kitchen 2008, Osarenkhoe 2008), the business network takes on three configurations:

1. The network of external unit identifies a whole range of companies that are strategically united in order to achieve a common objective. From an organizational point of view, the aggregate companies are separate.

2. The network of internal units. This is the case of a large company with a core business, and strategic business units with more, or less individual objectives;

3. The network on an inter-personal level which consist in relations, including those of a social nature, among several individuals within an organization.

The identification of other network models is generated from the network of external units, including the group of companies, hollow corporation, and the industrial district (Becattini, 1990).

Reference to the company networks is interpreted in a different manner according to the outlook of the investigation. This classification is in fact, regardless of the existence of formal or informal bonds between companies. Business networks operate with their own knowledge networks, named knets, which can expand beyond the boundaries of the company (Palmer and Richards 1999).

In this way, stable networks are distinguished from dynamic and internal ones. The first category corresponds to an alliance of a vertical nature between the companies that manage the network through strategic long term action. The second category is created by means of temporary agreements for the creation of individual company projects. The third category refers to the relationships that are created within a company.

The business network stands out from the network company, which can be interpreted among the various literary definitions (Gulati, 2007), as a set of several companies that are legally independent, but connected between them in the production process. 
The legal network can have one objective or several. It has been recently involved in norm related intervention, through the approval of the network contract. The network is the legal entity, and undertakes all entrepreneurial functions.

The regulation of company networks is sometimes implemented, as in the case of Italy, regulated by the law 122/2010 and subsequent modifications. Some aspects related to management and accounting are left to the discretion of the internal organizational processes of the networks. These can contribute to an increase in competitiveness and to the reaching of the objective.

This law refers to a theoretical framework for the creation of networks, continuing with indications related to the subject of the activity. This framework includes the network program and the creation of a (possible) financial fund. It also includes the formation of a (possible) common body and withdrawal from the aggregation. Furthermore, reference is made to some regulations related to legal subjectivity of the network (law 134/2012), and participation of the networks to tenders (law 221/2012). It is also important to remember the regulations of the law 224/2012 that refer to the tax credit give to the companies activating in research and development, or who entrust such activities to universities, public research authorities, and research organizations.

In 2013, according to the financial statements of Unindustria, there are more than 600 company networks that contain more than 3000 companies that have grown significantly from 2010. The most important problem regarding their operation is the difficulty in modifying the management model and the instruments used for company activities, in order to realize collaboration between the aggregates.

The norm regulations affect the management methods of the networks. In the case of examination, the networks of ex law 122/2010 may, for example, undertake legal subjectivity, adopting a governance model guided by a common body, to form a financial fund.

These aspects intervene in the management of networks, highlighting a framework useful for the construction of a management control system. In fact, it is important not to forget the importance of defining the aggregation as a systemic entity, or identifying an economic individual for undertaking strategic decisions. Activity planning, defining the long term objectives, and network programs allow a certain level of financial independence through the creation of a network fund. Once again the operative nature of the company network is identified and measured with reporting instruments. It has the objective of increasing competitiveness with regard to all of the stakeholders (Donaldson and Preston, 1995), and to implement the transfer of knowledge between companies in order to create value.

Therefore it is necessary to plan, assess, and measure activities carried out by the company network compatible with the actions of individual participating companies. This requires the use of adequate management control instruments.

These instruments can be used by each single company included in the network. The same need emerges in the network as the unitary organizational system.

In this way, the traditional understanding of the Anthony model (Broadbent, 2003)for planning and control systems need to be reviewed in light of the reticular model assigning new roles to the actors of the network. This reticular model modifies the organizational levels of strategic planning, management control, and operative control.

In company networks, these functions are aligned in a horizontal manner. All of the aggregate companies take part in the strategic decisions, except the ones undertaken by the mutual authority. If it exists, the forecast of a network manager acts as an intermediary. In terms of the information, activities, and operative technicalities of the system, operative controls are based on common network activities. 


\section{Methodology}

The qualitative research approach (Maylor and Blackmon, 2005) we adopted is based on the review of the literature related to management controls systems with special reference to the reporting instrument of the Balanced Scorecard. This methodology has been widely used in the last years in studies in management (e.g. Abatecola, Caputo, Mari, Poggesi, 2013; Caputo, 2013a; Caputo, 2013b). The objective of the organizational network model is to propose modern governance and to measure the instrument of joint performance. Scorecards have also been used in the field of knowledge management in order to define and interpret knowledge flows and identify the mechanisms through which they propagate (Grippa 2009).

These aspects allow for conceptualization of some problems related to business networks of a contractual nature, such as proposing a joint reporting system of financial and non financial performance of an intangible nature.

Through a single method approach, and following a similar procedure of previous research in the field of management (e.g. Abatecola, Caputo, Mari, Poggesi, 2013; Caputo, 2013a; Caputo, 2013b), data acquisition (Yin, 2014) was collected through secondary research sources. The following sources were used:

- Scientific books and articles (national and international),

- Public sources such as specialized websites, databases (ebsco, jstor, Google scholar, science direct) news, and various documents.

\section{Findings}

The results of research originate from an analysis of the previously indicated literature. The need to carry out management control in the business networks is generated by the diffusion of companies aggregation (Ackoff, 1961), whose objective is to achieve differential results that cannot be reached individually.

In order to do this, small and medium sized enterprises, as well as large companies participating in a network project may launch an improvement process of company culture, and of joint performance, through the adoption of a management control system that is common to the entire network. The general results of the entity must be identified in order to compare joint performance with that of the individual companies involved in the common project.

Existing literature presents the prerequisites of developing adequate monitoring systems of economic and non economic performance achieved by the companies (Kang and Fredin, 2012), proposing representation of the cause and effect relations between management, and the results achieved (Lebas and Euske, 2002), including those of an intangible nature.

In this regard, the Balanced Scorecard (BSC) is a modern reporting based on a balanced assessment form containing four company perspectives: economic-financial, customers, processes and learning and growth. Starting with this analysis, our research proposes use of the BSC model (Carr and Gratton, 2013) as a theoretical support for the construction of a management control system of business networks.

By keeping the logic of the BSC model unchanged, we propose a re-visitation according to the characteristics of the business networks, with special emphasis on the intangible components that characterize the nature of these organizations. For this objective, the network model identified is the one of the network contracts ex law 122/2010.

The legislative measures that characterize the formation of networks through contracts have been identified according to the analysis outlooks of the BSC.

Starting from the four perspective of the BSC (Mouritsen et al., 2005), it inserted a fifth profile based on the value creation (Marr et al., 2004), representing sustainable elements such 
as social and environmental responsibility and intellectual capital (Carlucci and Schiuma, 2007).

Definition of the new five perspective reports allows for the study of economic-financial, and intangible network performance (Petty and Guthrie, 2000) highlighting the objectives, and measures including a set of indicators that are useful to assess the general multidimensional activities without removing attention from the aggregate objectives from the unitary nature of the network system.

The introduction of a network assessment form, the Business Network Scorecard (BNS) allows, according to the interception logic, an assessment of general management of the company network. It is important to balance the objectives with the indicators, and the traditional perspectives with the modern ones, of an intangible nature. Furthermore, comparison charts of network performances are provided for as well as individual performances of each aggregate company.

We believe that the BNS reporting should consist of three parts:

- matrix of network objectives;

- multi-dimensional report (economic-financial, stakeholder, internal processes, development and creation of value), containing a set of network indicators;

- comparison chart of performance of the network companies.

The matrix of network objectives is the guideline of the management control system of business networks. The management control system principles of the network system are defined, and the common objectives that the cluster of companies must pursue are identified, with regards to each analysis instance.

The general objectives of the network of companies are the reference market of competitiveness, and the economic-financial returns deriving from joint activities. The customer perspective is connected with the creation of added value for customers (Freeman, 2010) from the network. The general objectives, for the purpose of internal processes are the creation of products and the supply of services demanded by the market. The perspective of development and growth implies the desire to adopt innovative processes (Chesbrough, 2003), as well as to make investments in intangible capital, both useful in achieving the whole series of objectives defined by the network.

The value creation perspective is connected with the added value generated by network, its intellectual capital, and the environmental impact of its activities. The BSC uses a scorecard that is in accordance to the principles of voluntary reporting, of sustainability, of value creation, which helps explain the aggregate strategic variables of an intangible nature.

\section{Discussion}

The multi-dimensional network report we propose is identified by means of a network assessment with five perspectives, containing a set of basic indicators (1-4 for each perspective) for management control of business networks: the measurement of results is based on the intersection of the companies activities.

The following chart (table 1) summarizes the findings through the five analysis perspectives, and a set of indicators that can be identified by using the BSC and the distinctive elements of the network contract.

\section{---- INSERT TABLE 1 ABOUT HERE ----}

In the economic-financial perspective of the multidimensional network report, the indicators are identified as follows: 
1. Share capital (financial fund). It identifies the value of share capital of the network, or the value of the financial fund, formed by the aggregate companies.

2. Profit or loss of the network. It defines the end of year results deriving from the activities carried out in common by the aggregate companies.

3. Proceeds. It represents the general turnover of the network with regards to the execution of activities.

4. Network activities value. The indicator originates from the total sum of the values of the assets acquired by the network.

5. Others. Indicators that can qualify the economic-financial perspective of the network.

In the customer perspective, whether they are external or internal to the network, the management control indicators of the network are identified as follows:

1. Number of customers involved in the network. It defines the number of customers of the network, characterized alternatively by the number of contracts undersigned by the network in its entirety.

2. Customer satisfaction rate. The satisfaction rate of customers from the network can be measured using the percentage of increase/decrease of turnover related to each customer of the network, or using the general turnover of the network, during one given year, compared with the turnover achieved during the previous year;

3. Number of complaints. It identifies the number of complaints received from customers of the network;

4. Network reputation. The network reputation is interpreted through the difference between the number of general relations with customers and the number of complaints received;

5. Others. Indicators used to qualify the customer perspective with regards to the network.

In the internal processes perspective the following indicators can be identified:

1. Number of the projects launched by the network. It represents the number or value of the research projects undertaken by the network in a given year.

2. Cost of products of goods and/or supply of services. It defines the total amount of costs borne by the network to produce its goods and/or to supply its services;

3. Number of employees of the network. It identifies the number of employees of the company network.

4. Equal opportunities. It defines the number of female and male employees of the network.

5. Others. Indicators used to qualify the perspective of internal network processes.

The network development perspective includes the following network indicators:

1. Value of investments in human capital training of the network. The indicator defines the value of investments made by the network for training its employees;

2. Number of process and product innovations. It identifies the number or value of innovations used in the production processes and/or in the distribution process;

3. Number of network patents. The indicator measures the number and/or value of the patents belonging to the network;

4. Investments in $R \& D$. It is the value of investments made by the network in research and development;

5. Other. Indicators used to define the perspective of the network development.

Due to the importance of the bond created between companies network, and the relations with the outside environment, measuring the creation of value implies considering intangible aggregate factors of a strategic nature.

The value creation perspective includes the indicators illustrated below: 
1. Added value of the network and social initiatives. It assesses the added value generated by the company network, through the general value of wages, including management authority (if available) and the network manager, the social initiatives, undertaken by the network, through the number and the value of investments undertaken for the organization of events with a social impact;

2. Environmental impact and certification. It defines the impact of the activities related with raw materials, energy, water and emissions. The indicator includes all of the initiatives undertaken by the network to mitigate the environmental impacts;

3. Stakeholder. The indicator identifies the number and the categories of network stakeholders;

4. Knowledge transfer. It qualifies the knowledge transfer realized between the companies of the network due to the effect of their collaborative alliance in term of network relations. Expressions of this indicator can be the knowledge assessment models (Cross et al., 2001);

5. Quality of the transactions. Indicators such as transaction costs (Choi et al., 1999), order delivery delays, supply material quality defections and missing orders, can be used to measure the quality of the business to business interactions within the network (Woo and Ennew, 2005, Walter et al., 2003). An example of indicators that can be used comes from the IMP interaction model, that has been proved to function as a valid and reliable measurement of relationship quality (Woo and Ennew, 2004).

6. Others. They are the other indicators used to qualify the perspective of analysis with regards to the characteristics of the network.

The aggregate multi-dimensional report builds a set of indicators of collaboration. They allow the company network to understand the effect of collaborative action, by comparing the dimensions of the single aggregate companies $\left(a_{1} a_{2}, a_{3}\right)$ with those of the network $(n)$, and defining the relational synergy of equality between the total of the dimensions related to each single company, and to the aggregate companies deriving from intersection (1). The formula is the following:

$$
\mathrm{a}_{1}+\mathrm{a}_{2}+\mathrm{a}_{3}=\mathrm{n}
$$

from which

$$
\mathrm{a}_{1}+\mathrm{a}_{2}+\mathrm{a}_{3}>\mathrm{n}
$$

and

$$
\mathrm{a}_{1}+\mathrm{a}_{2}+\mathrm{a}_{3}<\mathrm{n}
$$

The hypothesis in which the total amount of the dimensions of each single company is greater than the dimensions referred to the aggregation (2), may occur in the start-up phase of the network and, subsequently due to the effect of the trend in aggregate management throughout time. In this example, the effect of relational synergy generated by the network is presumably on the decrease. On the contrary, we can presume the hypothesis of an increase in relational network collaboration (3).

In this direction, the indicators are the following:

\section{---- INSERT THE TABLE 2 ABOUT HERE ----}

For example a reference can be made to the calculation of the indicator 2 , to time 0 , in the hypothesis of constitution of the company network by three companies with a portfolio of customers, respectively, equivalent to 20 . The customers of the network initially are 0 . The formula is the following: 


$$
\begin{gathered}
(20)+(20)+(20)=\mathrm{n}(0) \\
60>0
\end{gathered}
$$

In time 1 , due to the operative nature of the network, and of the management operations, the customer portfolio of each single aggregate company remains the same, while the network customers have increased by 90 . Therefore, we will find:

$$
60<90
$$

An increase in the customer portfolio of the network generated by its operative network should not be excluded. This result can also be explained by virtue of its competitive nature of the goods and services offered to the market compared with those of the single aggregate companies.

This report is based on the hypothesis that each company involved in the cluster adopts a similar management control system to the one proposed for the network. So, the individual and aggregate planning and control activities move towards an alignment.

The prerequisites for the management of the organization network model appear to be much more complex compared with the ones included in the analysis carried out up until now.

The necessity for creating an aggregate reporting system was born from the need to identify a governance and management model of company networks. For this reason, the essential elements of the network contract represent a guideline for the development of this system, in the perspective of measuring and control of the aggregate results.

The most important limits of the model proposed include the general nature of the reporting system in the contractual networks.

The best conceptualization of the elements that characterize our proposal needs to be confirmed through empirical research.

\section{Conclusion and future research directions}

We propose the organization of a management control system for networks organizational model through the innovative instrument of the Business Network Scorecard, inspired by the logic of the BSC of Norton and Kaplan.

This instrument finds its utility in the principles of planning and control of company activities, which are born from the strategic decisions that the networks must make and from the assessment, measuring and control of economic-financial performance as well as performance of an intangible nature generated by aggregation. It has the objective of establishing a certain level of aggregate competitive advantage and of generating differential value on the long term.

The three-party nature of the BNS system guidelines for implementation of the strategies and objectives of the network to create a multidimensional report containing a set of indicators for the five network perspectives, as well as identifying the collaboration effect generated by the network through some indicators, and comparing the results achieved by the network with the ones achieved individually.

The BNS is an integrated management control instrument; it would be capable of measuring the traditional and intangible results generated by the company networks according to intersection logic. Some critical aspects of an operative nature should not be neglected.

The framework proposed for network reporting is based on simplified hypotheses that need to be further defined according to the characteristics of each company network. 
This aspect also refers to completion of the set of indicators necessary to assess aggregate management regarding the profiles defined in representation of the strategic areas of the network.

The indicators of the BNS report as they may have homogeneous measures associated with them, resulting in the need for ad hoc interpretations, also by virtue of facts that may have occurred in several years that characterize reticular management, and/or management of other computer documents that summarize the joint action of the companies involved in the aggregation.

In this direction, the proposal for empirical controls aims at proving the importance of the management control instrument proposed, testifying the possibility of application of reporting and the meaning of the dimensions returned, especially by the indicators proposed. Contractual networks are a growing phenomenon; in Italy, just in the last few years, the number of network contracts grew from few tens to more than 1,500. Future research will need to collect data to test our proposed theoretical model. Sharing of data will be crucial for the success of the BNS report. Data and information sharing is usually mandated by the rules in the network contract and to growing formality of the network correspond a growing sharing of information. In some cases, such as the one of the business network with equity fund and common governance, data and information sharing within the network is mandated by the accounting rules. Indeed, those forms of network are bound to comply with the accounting disclosure rules of public companies.

Acknowledgements: This paper is the joint work of the three Authors, in particular paragraph 1 and 2.2 are by Andrea Caputo; paragraphs 2.1 and 6 are by Rosa Lombardi, paragraph 3 is by Vincenzo Formisano, and paragraphs 4 and 5 are by Giuseppe Russo. The authors would like to thank the Editor and the two anonymous reviewers for their extremely useful comments and suggestions. Moreover, the authors would like to express their gratitude to the anonymous reviewers and the participants to the Annual Conference of the Italian Academy of Management in 2013, who commented on an earlier version of this paper presented at that venue. 
Table 1 - Multidimensional Network Report

\begin{tabular}{|c|c|c|c|c|}
\hline $\begin{array}{l}\text { ECONOMIC- } \\
\text { FINANCIAL } \\
\text { NETWORK } \\
\text { PERSPECTIVE }\end{array}$ & CUSTOMERS & $\begin{array}{l}\text { INTERNAL } \\
\text { PROCESSES }\end{array}$ & $\begin{array}{l}\text { NETWORK } \\
\text { DEVELOPMENT }\end{array}$ & $\begin{array}{l}\text { VALUE } \\
\text { CREATION }\end{array}$ \\
\hline $\begin{array}{l}\text { Network Share } \\
\text { Capital (or } \\
\text { financial fund) }\end{array}$ & $\begin{array}{llr}\begin{array}{l}\text { Number } \\
\text { customers }\end{array} & & \text { of } \\
\text { included in } & \text { the } \\
\text { network } & \text { (or } \\
\text { number } \\
\text { contracts) }\end{array}$ & $\begin{array}{l}\text { Number of the } \\
\text { research projects } \\
\text { launched by the } \\
\text { network }\end{array}$ & $\begin{array}{l}\text { Value of } \\
\text { investments in } \\
\text { network human } \\
\text { capital training }\end{array}$ & $\begin{array}{l}\text { Added value of } \\
\text { the network and } \\
\text { social initiatives }\end{array}$ \\
\hline $\begin{array}{l}\text { Profit or Loss of } \\
\text { the network }\end{array}$ & $\begin{array}{l}\text { Customer } \\
\text { Satisfaction Rate }\end{array}$ & $\begin{array}{l}\text { Production cost of } \\
\text { goods and/or } \\
\text { supply of services }\end{array}$ & $\begin{array}{lr}\text { Number } & \text { of } \\
\text { process } & \text { and } \\
\text { product } & \\
\text { innovation } & \end{array}$ & $\begin{array}{l}\text { Environmental } \\
\text { impact and } \\
\text { certification }\end{array}$ \\
\hline Network proceeds & $\begin{array}{l}\text { Number } \\
\text { complaints }\end{array}$ & $\begin{array}{l}\text { Number of } \\
\text { employees of the } \\
\text { network }\end{array}$ & $\begin{array}{l}\text { Number of } \\
\text { network patents }\end{array}$ & Stakeholders \\
\hline $\begin{array}{l}\text { Network activities } \\
\text { value }\end{array}$ & $\begin{array}{l}\text { Reputation of the } \\
\text { network }\end{array}$ & $\begin{array}{l}\text { Equal } \\
\text { opportunities }\end{array}$ & Costs for R\&D & $\begin{array}{l}\text { Knowledge } \\
\text { transfer }\end{array}$ \\
\hline \multicolumn{5}{|c|}{ Other network indicators } \\
\hline
\end{tabular}

Source: our elaboration

Table 2 - Indicators of collaboration

\begin{tabular}{l|l} 
- Indicator 1 & It compares the total amount of share capital of each
\end{tabular} aggregate company with the network share capital. 


\begin{tabular}{|l|l|}
\hline - Indicator 2 & $\begin{array}{l}\text { It compares the total number of customers of each } \\
\text { aggregate company with the number of customers from } \\
\text { the network. }\end{array}$ \\
\hline - Indicator 3 & $\begin{array}{l}\text { It compares the total number of research projects } \\
\text { launched by each single aggregate company with the } \\
\text { number of research projects launched by the network. }\end{array}$ \\
\hline - Indicator 4 & $\begin{array}{l}\text { It compares the total number of investments in terms of } \\
\text { wages and training of human capital of each single } \\
\text { aggregate company with the value of investments in } \\
\text { wages and training of human capital of the network. }\end{array}$ \\
\hline
\end{tabular}




\section{Bibliography}

Abatecola, G., Caputo, A., Mari, M., \& Poggesi, S. (2013). 'Real Estate Management: Past, Present and Future Research Directions.' International Journal of Globalisaton and Small Business, 5:1/2, 98 - 113.

Ackoff, R. L. (1961). 'Systems, organizations and interdisciplinary research.' In D. P. Eckman (Ed.) Systems: Research and design. New York, NY: J. Wiley \& Sons.

Ahmad, S. Z., \& Kitchen, P. J. (2008). 'Transnational corporations from Asian developing countries: the internationalisation characteristics and business strategies of Sime Darby Berhad.' International Journal of Business Science and Applied Management, $3: 2,21-36$.

Anthony, R. N. (1965). 'Management planning and control systems: A framework for analysis.' Harvard Business School Press, Boston.

Austin, R. \& Gittell, J. H. (2002). When it should not work but does: Anomalies of high performance. Cambridge University Press: Cambridge.

Becattini, G. (1990). 'The Marshallian industrial discrict as socio-economic notion.' In F. Pyke, G. Becattini \& W. Sengenberger (Eds.) Industrial disctric and inter-firm cooperation in Italy: 37-51. Geneve, Switzerland: International Institute for Labour Studies.

Broadbent, M. (2003). Managing financial resources. Elsevier.

Bunderson, J. S. \& Reagans, R. E. (2011). 'Power, Status, and Learning in Organizations.' Organization Science, 22:5, 1182-94.

Camillus, J. C. (1986). Strategic planning and management control: Systems for survival and success. Lexington Books.

Capasso, A., Dagnino, G. B. \& Lanza, A. (2005). Strategic capabilities and knowledge transfer within and between organizations: new perspectives from acquisitions, networks, learning and evolution. Edward Elgar Publishing.

Caputo, A. (2013a). 'A Literature Review of Cognitive Biases in Negotiation Processes.' International Journal of Conflict Management, 24(4), 274-398.

Caputo, A. (2013b). 'The Third Who Joins a Negotiation: a Systematic Review of the Literature.' International Journal of Business and Globalisation, 10(3), 256-277.

Carlucci, D. \& Schiuma, G. (2007). 'Knowledge assets value creation map: assessing knowledge assets value drivers using AHP.' Expert Systems with Applications, 32:3, 814-21.

Carr, L. P. \& Gratton, S. (2013). 'Scorecard sustainability: Discovering the inflection point for business scorecard termination or major alteration.' Journal of Corporate Accounting \& Finance, 24:3, 25-37. 
Chesbrough, H. W. (2003). Open innovation: The new imperative for creating and profiting from technology. Harvard Business Press.

Choi, C. J., Lee, S. H., \& Kim, J. B. (1999). 'A note on countertrade: contractual uncertainty and transaction governance in emerging economies.' Journal of International Business Studies, 189-201.

Coase, R. H. (1937). 'The nature of the firm.' Economica, 4:16, 386-405.

Cross, R., Parker, A., Prusak, L. \& Borgatti, S. P. (2001). 'Knowing what we know:: Supporting knowledge creation and sharing in social networks.' Organizational Dynamics, 30:2, 100-20.

Cruz, L. B. \& Boehe, D. M. (2008). 'CSR in the global marketplace: Towards sustainable global value chains.' Management Decision, 46:8, 1187-209.

Dagnino, G. B. (2004). 'Complex systems as key drivers for the emergence of a resource-and capability-based interorganizational network.' Emergence: Complexity and Organization, 6:1-2, 61-69.

Del Giudice, M., Maggioni, V., Chase, R. \& Chase, R. (2014). 'Managerial practices and operative directions of knowledge management within inter-firm networks: a global view.' Journal of Knowledge Management, 18:5.

Donaldson, T. \& Preston, L. E. (1995). 'The stakeholder theory of the corporation: Concepts, evidence, and implications.' Academy of Management Review, 20:1, 65-91.

Ebrahimi, M., Saives, A.-L. \& Holford, W. D. (2008). 'Qualified ageing workers in the knowledge management process of high-tech businesses.' Journal of Knowledge Management, 12:2, 124-40.

Flamholtz, E. (1996). Effective management control: theory and practice. Springer.

Freeman, R. E. (2010). Strategic management: A stakeholder approach. Cambridge University Press.

Gollin, M. A. (2008). Driving Innovation. Cambridge University Press.

Goold, M. \& Campbell, A. (2003). 'Structured networks: towards the well-designed matrix.' Long Range Planning, 36:5, 427-39.

Grandori, A. \& Soda, G. (1995). 'Inter-firm networks: antecedents, mechanisms and forms.' Organization Studies, 16:2, 183-214.

Grant, R. M. (1996). 'Toward a Knowledge "Based Theory of the firm.' Strategic Management Journal, 17:S2, 109-22.

Grippa, F. (2009). ' A social network scorecard to monitor knowledge flows across communication media', Knowledge Management Research \& Practice, 7, 313-328.

Gulati, R. (2007). Managing network resources: alliances, affiliations and other relational assets. Oxford University Press Oxford. 
Gulati, R., Nohria, N. \& Zahee, A. (2000). 'Strategic Networks.' Strategic Management Journal, 21:3, 203-15.

Johnson, J. D. (2009). Managing Knowledge Networks. Cambridge University Press.

Kang, G. G. \& Fredin, A. (2012). 'The balanced scorecard: the effects of feedback on performance evaluation.' Management Research Review, 35:7, 637-61.

Kaplan, R. S. \& Norton, D. P. (1996). The Balanced scorecard: translating strategy into action. Harvard Business Press.

Kaplan, R. S. \& Norton, D. P. (2001). 'Transforming the balanced scorecard from performance measurement to strategic management: Part I.' Accounting horizons, $15: 1,87-104$.

Lebas, M. \& Euske, K. (2002). 'A conceptual and operational delineation of performance.' Business performance measurement: Theory and practice, 65-79.

Lev, B. (2000). Intangibles: Management, measurement, and reporting. Brookings Institution Press.

Lin, M.-J. J. \& Chen, C.-J. (2008). 'Integration and knowledge sharing: transforming to longterm competitive advantage.' International Journal of Organizational Analysis, 16:1/2, 83-108.

Lynch, J. G., Jr., Chakravarti, D. \& Mitra, A. (1991). 'Contrast Effects in Consumer Judgments: Changes in Mental Representations or in the Anchoring of Rating Scales?' Journal of Consumer Research, 18:3, 284-84.

Lombardi, R., Trequattrini, R. \& Battista, M. (2014). 'Systematic errors in decision making processes: the case of the Italian Serie A football championship' International Journal of Applied Decision Sciences, 7:3, 239-254.

Marr, B., Schiuma, G. \& Neely, A. (2004). 'The dynamics of value creation: mapping your intellectual performance drivers.' Journal of Intellectual Capital, 5:2, 312-25.

Maylor, H. \& Blackmon, K. L. (2005). Researching business and management. Palgrave Macmillan.

Mentzas, G., Apostolou, D., Young, R. \& Abecker, A. (2001). 'Knowledge networking: a holistic solution for leveraging corporate knowledge.' Journal of Knowledge Management, 5:1, 94-107.

Mouritsen, J., Larsen, H. T. \& Bukh, P. N. (2005). 'Dealing with the knowledge economy: intellectual capital versus balanced scorecard.' Journal of Intellectual Capital, 6:1, 827.

Myers, M. D. (2013). Qualitative research in business and management. Sage. 
Nohria, N. (1994). Networks and organizations: structure, form and action. Cambridge, MA: Harvard University Press.

Normann, R. \& Ramirez, R. (1993). 'Designing interactive strategy.' Harvard Business Review, 71:4, 65-77.

Norreklit, H. (2000). 'The balance on the balanced scorecard a critical analysis of some of its assumptions.' Management Accounting Research, 11:1, 65-88.

Osarenkhoe, A. (2008). 'A study of the enablers of non-sequential internationalization process among small and medium-sized firms.' International journal of business science and applied management, 3:2, 1-20.

Otley, D. (1999). 'Performance management: a framework for management control systems research.' Management Accounting Research, 10:4, 363-82.

Palmer, J., Richards, I. (1999). 'Get knetted: network behavior in the new economy', Journal of Knowledge Management, 3:3, 191-202.

Parkhe, A., Wasserman, S. \& Ralston, D. A. (2006). 'New frontiers in network theory development.' Academy of Management Review, 31:3, 560-68.

Petty, R. \& Guthrie, J. (2000). 'Intellectual capital literature review: measurement, reporting and management.' Journal of Intellectual Capital, 1:2, 155-76.

Porter, M. E. (1991). 'Towards a dynamic theory of strategy.' Strategic Management Journal, $12: \mathrm{S} 2,95-117$.

Powell, W. (2003). 'Neither market nor hierarchy.' The sociology of organizations: classic, contemporary, and critical readings, 315, 104-17.

Reginato, L. \& Guerreiro, R. (2013). 'Relationships between environment, culture, and management control systems.' International Journal of Organizational Analysis, 21:2, 219-40.

Rogers, E. M. \& Kincaid, D. L. (1981). 'Communication networks: Toward a new paradigm for research.'

Roos, J., Edvinsson, L. \& Roos, G. (1998). Intellectual capital: Navigating in the new business landscape. New York University Press.

Rouse, P. \& Putterill, M. (2003). 'An integral framework for performance measurement.' Management Decision, 41:8, 791-805.

Schönström, M. (2005). 'Creating knowledge networks: lessons from practice.' Journal of Knowledge Management, 9:6, 17-29.

Shutibhinyo, W. (2013). 'Balanced Scorecard Attributes: Key Determinant and Perceived Benefits.' Global Journal of Business Research, 7:2, 1-8.

Tangen, S. (2004). 'Performance measurement: from philosophy to practice.' International Journal of Productivity and Performance Management, 53:8, 726-37. 
Thorelli, H. B. (1986). 'Networks: between markets and hierarchies.' Strategic Management Journal, $7: 1,37-51$.

Trequattrini R., Russo G. \& Lombardi R. (2012). 'The Crisis of Company Networks and Tools for its Prediction'. International Business Research, 5:10, 46-55.

Trequattrini R., Russo G. \& Lombardi R. (2012). 'Network Governance: organisational and legal profiles'. Corporate Ownership \& Control, 9:4, 346-350.

Von Hippel, E. (2007). The sources of innovation. Springer.

Walter, A., Müller, T. A., Helfert, G., \& Ritter, T. (2003). 'Functions of industrial supplier relationships and their impact on relationship quality.' Industrial Marketing Management, 32(2), 159-169.

Williamson, O. E. (1991). 'Comparative economic organization: The analysis of discrete structural alternatives.' Administrative Science Quarterly, 269-96.

Winter, S. (1998). 'Knowledge and competence as strategic assets.' The strategic management of intellectual capital, 165-87.

Winter, S. G. (2003). 'Understanding dynamic capabilities.' Strategic Management Journal, 24:10, 991-95.

Woo, K.S., \& Ennew, C. T. (2004). 'Business-to-business relationship quality: An IMP interaction-based conceptualization and measurement'. European Journal of Marketing, 38:9/10, 1252-1271.

Woo, K.S., \& Ennew, C.T. (2005). 'Measuring business-to-business professional service quality and its consequences'. Journal of Business Research, 58:9, 1178-1185.

Yin, R. K. (2014). Case study research: Design and methods. Sage publications.

Yoon, W. \& Hyun, E. (2010). 'Economic, social and institutional conditions of network governance: Network governance in East Asia.' Management Decision, 48:8, 121229. 